\title{
The Effect of a Listening Education Course on the Listening Behaviors of Prospective Turkish Teachers
}

\author{
Talat Aytan ${ }^{1}$ \\ ${ }^{1}$ Department of Turkish Education, College of Education, Yildiz Technical University, Istanbul, Turkey \\ Correspondence: Talat Aytan, Department of Turkish Education, College of Education, Yildiz Technical University, \\ Istanbul, Turkey. E-mail: talataytan@ gmail.com
}

Received: March 27, 2016

Accepted: April 11, 2016

Online Published: April 17, 2016

doi:10.5430/ijhe.v5n2p254

URL: http://dx.doi.org/10.5430/ijhe.v5n2p254

\begin{abstract}
This study aims to determine the effect of a listening education course on the listening behaviors of prospective Turkish teachers. The participants of the study are 45 prospective teachers who are studying at a state university in Istanbul and taking a listening education course. The study is an experimental study in the model of 'one group pre-test - post-test' . The "Listening Skills Scale" course developed by Cihangir Cankaya (2012) was applied to the prospective teachers before taking the course as a pre-test and after taking it as a post-test. According to pre-test results, the "Listening Skills Scale" pre-test average of the prospective teachers was identified as 50.73. Their post-test average was 64.51. The Listening Education course has created an awareness in prospective Turkish teachers of listening types and has increased their levels of sensitivity in using body language. These prospective teachers also now showed a tendency towards avoiding the negative listening behaviors.
\end{abstract}

Keywords: Turkish teachers, Listening course, Listening behaviors, Experimental study

\section{Introduction}

Turkish education system aims to develop the basic language skills for all learners. These skills are the sub- skills of comprehension skills which are listening, reading, visual reading; and the sub-skills of narration skills which are presentation, speaking and writing. Listening is the first mother tongue event of a child, s/he learns most of the knowledge during the pre-school period through listening" (Ozdemir, 1987: 166). When considered about the time children spend by listening and the role of listening on language development and learning, the necessity of systematically teaching of listening must be emphasized in all programs, particularly in the primary school curriculum (Cossitt, 1978). In addition, Aytan (2011) argues that considering the fact that the tools such as; radio, television, telephone, etc. brought by technology, the artistic activities such as; drama, movie and music, and the activities for instance; meetings, conferences, panels are utilized by the way of listening; and the exchange of information in everyday life are conducted by listening, the importance of listening skills cannot be denied.

Listening skill is the communication process, according to Johnson (1951) and Hampleman (1958), while it is to distinguish words from recognizing other words. Wolff et al. (1983) define listening skill as a process of understanding that includes hearing and a process of establishing meanings which aims to integrate the old and new information. Rost (1994) describes this skill as a comprehension instrument that we use unconsciously in our daily lives. Jalongo (1995) specifies listening as a mental activity to understand the messages to be delivered, while Ozbay (2005) describes the skill as "an activity to understand verbal messages correctly" (p. 11), and Kecik and Uzun (2004:111) entitle listening as "a process of understanding and interpreting a verbal input". Listening is a complex and multi-stage process in which spoken language is transformed to a meaning in mind (as cited in Akyol, 2010: 1).

Listening (Ciftci, 2001) which is one of the four basic functions of language and an indispensable element of communication between individuals has been offered in a course of undergraduate programs since 2007. According to the Higher Education Institute Education Faculty Teacher Education programs, the Understanding Techniques II (Listening Education) course has the following content: Doing activities which develop listening skill, clarifying the process of productivity and functioning of listening activity benefiting from psychological researches; determining of attention spans; remarking of memory retention and comprehension studies. Listening and understanding universally by using a variety of audio and visual communication tools, sampling of selective 
listening- comprehension activities. Demonstrating and introducing various listening-comprehension exercises to the prospective teachers for them to use in primary school Turkish lessons, and giving them opportunities to develop these exercises. Performing a variety of listening exercises in the classroom (The Council of Higher Education, 2007).

The listening education course introduces the aims and attainments of the Turkish curriculum and theoretical and practical studies have been being made through lesson plans. There are 42 attainments in the Turkish Education Program and they are: applying the rules of listening/watching, understanding and analyzing the listened the watched, assessing the listened /the watched, enriching the vocabulary, gaining effective listening/watching habits". Listening course texts should be appropriate to the student level and should have a wide variety of vocabulary in terms of length and vocabulary.

Since the program allows a maximum of ten-minute listening time for secondary school students, no long listening texts are allowed. One of the important issues of listening education is listening to different types of texts, of course. When the literature is examined, many different classifications of listening types can be found. Gogus (1978) states that there are three different listening types: careful listening, proper listening, and critical listening. Aytas (1999) divides listening into five types as passive, selective, participative, emotional and critical. Oz (2001) classifies listening as listening to have knowledge, listening to follow conversations, listening what is spoken, listening while students reading aloud, and listening to a drama or a chorus. According to Tompkins (1998), listening types are distinctive listening, aesthetical listening, transferring listening, critical listening and therapeutical listening (quo. Akyol, 2010: 10). Cuceloglu (2009), Umagan (2007) and Cihangir (2004) compile listening under two main headings including effective and ineffective listening, while Gunes (2007: 92-93) mentions listening types as the following: Listening by following the text, inquisitive listening, creative listening, passive listening, participative listening and listening by note taking. To Ozbay (2005), listening types are: voluntary or involuntary listening, motivation based listening, listening with sympathy or antipathy, selective listening, superficial listening, active listening, participative listening, critical listening and passive listening.

Listening education courses focus on the characteristics of the listening texts. Teachers have been trained to prepare the questions towards understanding the listened people. The importance of not only verbal messages but also non-verbal messages are emphasized with regard to the importance of listening in communication. Research shows that people care about how you say instead of what you say in daily life (Dokmen, 1994: 27). "Only 35\% of communication between two people is verbally (oral), 65\% of it is nonverbal" (Hubler, 2001: 11). In this respect, a listening education course also informs us about non-verbal behaviors such as; eye contact, facial expressions, and sitting and postural manners or body language.

There are not many studies about the listening behaviors of Turkish teachers in the literature. Cihangir (2004) revealed that effective listening courses given to the university students have developed their listening skills positively. In Emiroglu's study(2013) where he tried to determine prospective Turkish teachers' listening problems; these problems often originated from the speakers, and the speaker's way of speaking, her/his knowledge of speaking techniques, and her/his behaviours. In addition, components such as; psychological and physiological factors, topic and environment were underlined as recipient based problems in understanding listening skills.

According to Kurudayioglu and Kana's (2013) research, prospective Turkish teachers find themselves adequate in the matters of; " planning activities for the listening education, preparing a listening activity plan, selecting an appropriate method for listening activities and choosing appropriate supplies for listening activities" (p. xx), while they feel themselves incompetent in "making students discuss constructively regarding listening texts ", "helping students connect what they listened to with their own experiences", making students comprehend the importance of listening and providing them to listen by taking notes.

Maden and Durukan (2011) concentrated on passive and participative listener styles of prospective Turkish teachers. Likewise, in Tabak (2013)'s research, prospective Turkish teachers was seen to have passive listeners' and participants listeners' attitudes. Temur (2010) confirmed that the effect of the pre-text questions on level of comprehending skills the listened people parts was greater thanthe post-test questions of the text. It was not seen any gender based differences in terms of understanding level of the listened people part. Dogan and Ozcakmak (2014) determined that summarizing skills of prospective teachers what they listened were a bit above average.

Since the listening skills studies have been limited, communication and listening skills of other prospective teachers who were studying in education faculties were also addressed in this study. Yoncalik and Cimen (2006)'s study on the students of physical education and elementary teachers has found that the listening skills of both departments' students were in"medium" level. The results of Durmusoglu, Saltalı and Erbay (2013)'s study showed that pre-school 
teachers love the children who developed listening, speaking and empath skills most and this has a meaningful descriptor.

In the research conducted by Dilekmen et al. (2008), no significant differences between the first year and fourth year university students were found in terms of development of their communication skills. However, Pehlivan's (2005) study has found a significant difference between first and fourth year students in favor of final year students. In addition, in Yesil's (2009) study, communication skills of teachers were detected as adequate. Development of listening skills which is one of the comprehension skills is important in terms of demonstrating Turkish teachers' professional development and their having effective communication skills. In this context, this study aims to determine the effect of an undergraduate course named Understanding Techniques II: Listening Education on the listening skills of prospective Turkish teachers.

\section{Methodology}

\subsection{Research Design}

In this study a descriptive quantitative research was employed. This study is an experimental work in the model of "one group pre-test - post-test". In this model of "one group pre-test -post test model", an independent variable is also applied to a randomly selected group. But this time, there are both before (pre-test) and after (post-test) measurements available (Karasar, 2009: 96). In the study, purposive sampling method was used, convienenve sampling was preferred because of its time and place advantages (Buyukozturk, 2010).

\subsection{Participants}

This study was conducted in the fall semester of the 2014-2015 academic year, after obtaining the ethics committee permissions. The participants of this study consisted of 45 prospective Turkish teachers who were studying in a state university in Istanbul and taking the "Understanding Techniques II: Listening Education" course. 16 of theprospective teachers were males and 29 of them were females. All of them were applied a pre-test before taking the "Understanding Techniques II: Listening Education" course, when the "Understanding Techniques II: Listening Education" course ended 14 weeks later, a post test was applied to them after taking the course.

\subsection{Data Collection and Analysis}

In this study, as a data collection tool, a scale "Listening Skills Scale" developed by Cankaya Cihangir (2012) was used. Its confirmatory and explanatory factor analysis had been conducted before. The Scale's 1st, 3rd, 4th, 6th, 7th and 10th articles have contained negative expressions (See Appendix A). In order to compare pre-test and post-test results of these articles, the values of scale were rivesed while obtaining the total score. The collected data were analyzed in the SPSS 17:00 program.

\section{Results}

The data collected from the prospective teachers were subjected to a paired $t$ test. According to pre-test results, the pre-test average of the prospective teachers' "Listening Skills Scale " has been identified as 50.73. The post- test average was obtained as 64.51 . The value of significance according to the $T$ test has been found as $p(0.000)$. Since this value is smaller than the value of 0.001 , it can be said that there is a statistical difference between pre-test and post-test results (Aydin \& Aslan, 2016). Accordingly, the average values of post-test results are approximately 4 points higher than the average values of pre-test results and the difference is statistically significant, as well. The given listening education has made a positive impact on the listening skills of prospective teachers.

Table 1. Descriptive statistical values of pre test- post test

\begin{tabular}{llll}
\hline & N & Average & Standard Deviation \\
\hline Pre- Test & 45 & 50,73 & 4,67 \\
\hline Post- Test & 45 & 64,51 & 4,21 \\
\hline
\end{tabular}

The data collected in order to test if there is a difference in the listening skills of prospective teachers on the basis of gender have been subjected to the independent sample $t$ test. Accordingly, the significance level was found as $\mathrm{p}$ (0.08). Since $p$ was bigger than 0.05 ( $p>0.05$ ), there was no significant difference on the development of listening skills on the basis of gender. However, when the following chart is viewed, it can be said that although there is no statistically significant difference, male teachers made better progress on listening skills. 


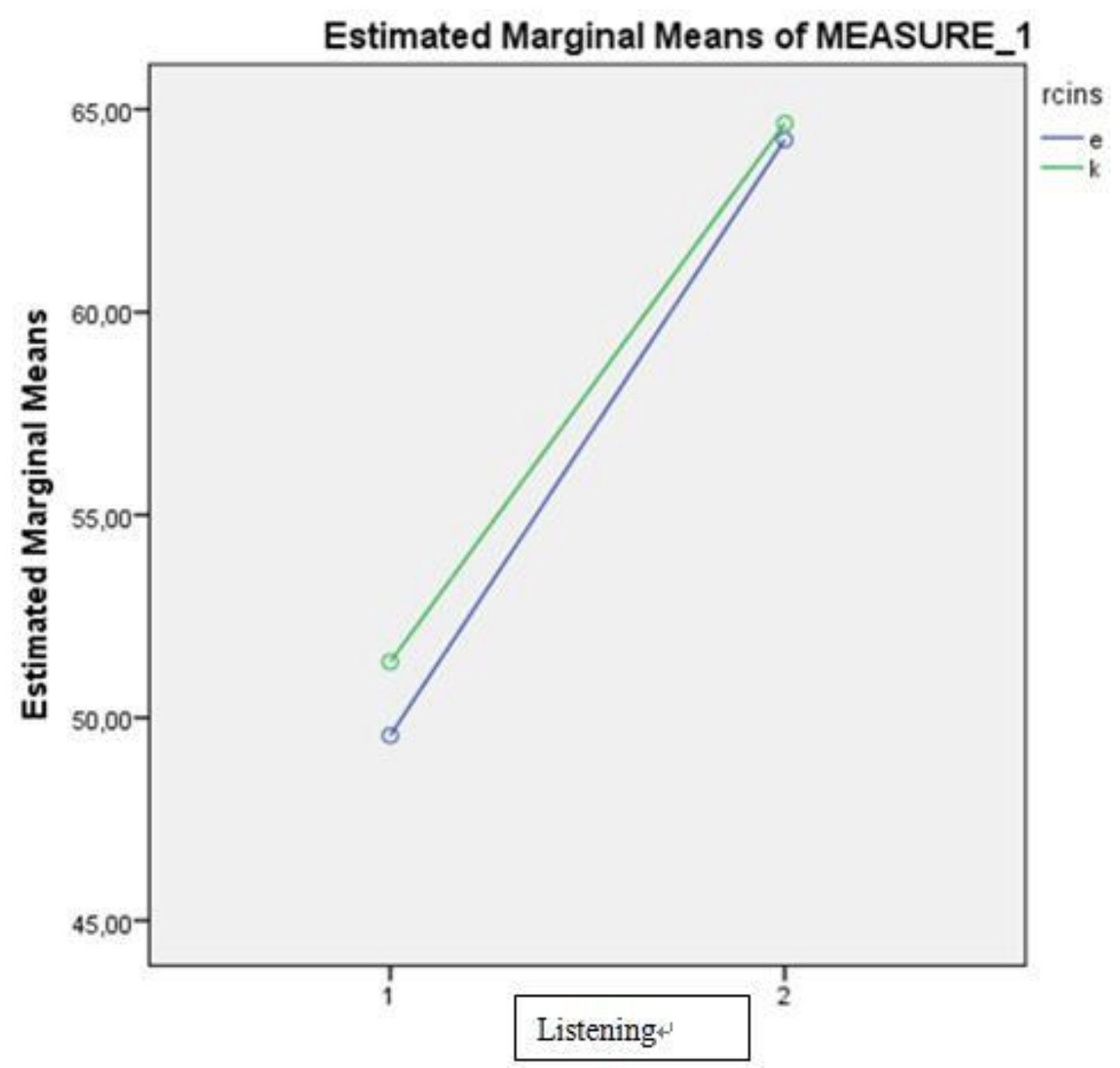

Figure 1. 
Table 2. Descriptive statistics of the means of measure

\begin{tabular}{llllll}
\hline Means No & N & Average of Pre-test & $\begin{array}{l}\text { Standard } \\
\text { Deviation }\end{array}$ & $\begin{array}{l}\text { Average of } \\
\text { Post-test }\end{array}$ & $\begin{array}{l}\text { Standard } \\
\text { Deviation }\end{array}$ \\
\hline 1 & 45 & 2,57 & 1,01 & 3,86 &, 72 \\
2 & 45 & 3,97 & 1,01 & 4,80 &, 50 \\
3 & 45 & 2,93 & 1,09 & 3,55 &, 81 \\
4 & 45 & 2,64 &, 90 & 3,62 &, 61 \\
5 & 45 & 4,04 & 1,12 & 4,82 &, 49 \\
6 & 45 & 2,82 & 1,21 & 3,66 &, 87 \\
7 & 45 & 2,48 &, 92 & 3,86 &, 72 \\
8 & 45 & 4,06 &, 78 & 4,75 &, 57 \\
9 & 45 & 4,02 &, 96 & 4,68 &, 70 \\
10 & 45 & 2,44 &, 94 & 3,91 &, 70 \\
11 & 45 & 3,91 &, 82 & 4,60 &, 75 \\
12 & 45 & 2,00 & 1,04 & 4,04 &, 97 \\
13 & 45 & 4,17 &, 80 & 4,73 &, 68 \\
14 & 45 & 4,33 &, 79 & 4,75 &, 57 \\
15 & 45 & 4,28 & 4,82 &, 49 \\
\hline
\end{tabular}

The pre-test average of the scale's second article which is " I ask questions to understand better the person whom I am talking to" is" $3.97 "$ while the post- test average of it rose up to "4.80". Listening types take places in the listening education curriculum. Among these listening types, ideal listening types are "active" or "participative" listening types. In active listening, the listener concentrates on what s/he listens to, and he participates actively in the process of understanding by asking questions and giving feedback. In this regard, students' asking questions in order to develop a better understanding of their interlocutors can be interpreted as they developed an awareness of listening types in the curriculum. However, associated with active listening, the pre-test average of the fifth article of the scale which is " I try to make the person I am talking to feel that I am willing to understand him/her better" was " 4.04 ", but the post-test average of it increased as of " 4.82 ". The pre-test average of the scale's seventh article which is " There are times when I don't listen to someone whom I am talking to" is" 2.48 " while the post- test average of it is" $3.86 "$ ". As mentioned above, the development of this behavior indicated that student teachers gained sensitivity towards listening types, specific to active listening (Yurtseven \& Altun, 2015). "The more teachers master in active listening, the more they are able to apply this skill in various situations at schools, in their family lives and in their relations with all people" (as cited in Ciftci, 2007: p. 235).

The pre-test average of the scale's eighth article which is " Understanding the person's feelings and thoughts while listening, I can transfer those feelings to him/her by my verbal or non-verbal behaviors" is"4.06" while the post- test average of it rose up to "4.75". The pre-test average of the scale's ninth article which is " When a conflict occurs, I try to listen patiently to the person whom I am talking to understand her/his feelings and thoughts better" is" 4.02 " while the post- test average of it rose up to "4.68". The pre-test average of the scale's eleventh article which is " While listening to someone, I try to put myself into her/his shoes." is" 3.89 " while the post- test average of it rose up to "4.60". The pre-test average of the scale's fifteenth article which is "While listening to someone, I try to understand her/his feelings" is" 4.28 " while the post- test average of it rose up to "4.82". When the scale's eighth, ninth, eleventh and fifteenth articles are examined, it can be seen that the article contents are aimed at empathical 
listening. Prospective teachers have increased their interest to empathical listening in the result of listening education. Additionally, the pre-test average of the scale's first article which is "I get bored to listen to the people who don't think like me" is " 2.57 ", while the post-test average of it is " 3.86 ". The pre-test average of the scale's third article which is "I don't like listening to others for a long time" is " 2.93 ", when the post-test average of it is " 3.55 ". The pre-test average of the scale's sixth article which is "I believe that I don't have to listen to others for a long time" is " 2.82 ", when the post-test average of it is " 3.66 ". These data also have importance as it showed empathical behaviors of the students, for instance; even if they did not agree with the people, they were kindly able to listen to them and they improved their tolerance levels while listening. To Pala (2008), empathy levels of prospective teachers came slightly above average. With regard to teaching profession, it is useful to emphasize the importance of empathy skills. According to Yuksel (2004), man needs to establish relationships with others in every period of his life. The success of this relationship depends on his understanding and accepting himself and others. Yuksel aslo argued that "individuals' learning to be tolerant and respectful each other's views and ideas is very important in order to create a democratic society" (p. 342). The teaching profession is a profession that requires empathy skills (Akbulut and Saglam, 2010). Teachers with effective communication should also develop their empathy, listening and speaking skills (Arabaci, 2012; Erbay, Omeroglu and Cagdas, 2012; Gordon, 1996).

The pre-test average of the scale's thirteenth article which is "While listening to someone, I would make sure that my body faces towards him/her" is " 4.17 ", when the post-test average of it rose up as " 4.73 ". When the pre-test average of the scale's fourteenth article which is "While listening to someone, I care about her/his verbal and non-verbal messages" is " 4.33 ", the post-test average of it rose up as " 4.75 ". While the pre-test average of the scale's twelfth article which is "I have a difficulty to make an eye contact the person whom I am listening to" is "2.00", the post-test average of it became "4.04". An effective listening is directly proportional to using of body language effectively. In particular, the establishment of eye contact between the listener and the interlocutor is important in terms of an effective communication. The increase of sensitivity of the students about the body language is remarkable. According to Schober (2007: 116), having a meaning from the point of non-verbal communication, body language is a set of values consisting of facial expressions, gestures and body postures which are used to be transferred the person's feelings and thoughts. Due to carrying a quality which needs the effective usage of language, the teaching profession is important in terms of the ability of using body language and the fulfilling of successful education that is a communication process (Gokceli, 2013: 545). Teacher should benefit both verbal and body language effectively in order to accomplish in the education process" (Habaci et al.2013: 1344). In Pektas (1998), Caliskan (2003), Yesil's (2006) studies, it has been stated that the teachers were insufficient about using of body language.

The pre-test average of the scale's tenth article which is "There are times when I pretend to listen to someone even though I don't listen to him/her" is " 2.44 ", the post-test average of it rose up as "3.91". While the pre-test average of the scale's fourth article which is "My thoughts shift into another field while listening to someone" is "2.64", the post-test average of it became as " 3.62 ". These data indicate that prospective teachers avoided the negative listening behaviors in the result of listening education.

\section{Discussion and Conclusion}

According to the results of this study which tried to identify the effect of listening education course on the listening behaviors of propective teachers, listening education course has created an awareness on the teachers towards listening types. Prospective teachers have made progress in terms of asking questions to the interlocutor for active listening, make him/her feel that they listen, keeping eye contact, and focusing attention in the listening process. However, they showed improvment in gaining the empathy skill which is an important value in human relations (Lafer, 2014), understanding the intricacies of empathical listening, and being more tolerant to others or those who are against them. In addition, prospective teachers have also developed a positive attitude about "pretending as if he/she listens" and "shifting his/her thoughts to other fields while listening to". Finally, teachers have developed a positive attitude displaying the behaviors of ;"facing the body towards the speaker, establishing eye contact" in terms of a communication element which is called non-verbal behavior or body language. In according to Ozkan's (2011)research, prospective Turkish teachers see the comprehension techniques course which includes listening education and reading education as important and functional in their lives. In addition, they have also found adequate these courses' contents and time zones allocated for theory and practice. Mert (2013), in his study which analyzed the basic language skills' perceptions of prospective Turkish teachers through metaphors, has described $25 \%$ of the listening skills of teachers as"a valuable action", while $18 \%$ of listening skills of them as "a need", $16 \%$ of their skills as"an action through the life" and $15 \%$ of them as "an element of communication. When looked at the metaphors produced by the prospective teachers, it was observed that they reviewed listening skills as extremely important actions. 
Prospective teachers' taking listening education course seriously is important in terms of the development of their listening behaviors both in their professional lives and in their educational environment. In contrast to Tabak's (2013) research results, prospective Turkish teachers have developed a positive attitude towards listening education course in terms of listening types, positive listening behaviors and body language. Effective communication skills can be facilitating relationships in all kinds of human relations and in all types of professional fields (Korkut, 2005: 143). "Owing to being more self-confident, more sociable and more open to interaction, the attitudes of prospective teachers with communication skills towards the profession were affected in a positive way" (Tunceli, 2013: 56). Finally, the teachers showing effective listening behaviors can be stated naturally that they can improve their students' listening skills as being a role model.

Among basic language skills, listening skill which is the first developed language skill in the language aquisition process is an effective and inexpensive way to learn in the individual's learning experiences. People have knowledge using their listening skills at school, at work and in daily lives. Prospective Turkish teachers' internalising the importance of listening skills, when they started teaching profession after graduating from an undergraduate program has a great importance. Developing sensibility towards listening process, listening types, non-verbal messages during the listening, and positive listening behaviours, prospective Turkish teachers will play a leading role in bringing these skills to students properly. According to the Turkish Education Programme adopting thematic approach, a listening text must be studied in each theme at least. Positive developments on the listening behaviors of prospective Turkish teachers who took the Listening Education course will provide them to apply an effective teaching-learning process to their students through listening texts and listening behaviors.

\section{References}

Akyol, H. (2010). Turkish Teaching Methods. Ankara: Pegem Academy Publications.

Akbulut, E., \& Saglam, H.I. (2010). Examination of empathetical tendency levels of classroom teachers. International Human Sciences Journal 7(2), 1068-1083.

Arabaci, N. (2012). G. Karadeniz \& E. Aktan Kerem (Ed). Parent-child-teacher communication in pre-school period. G. Karadeniz \& E. Aktan Kerem (Ed). An in-depth look through early childhood, ideas, shares, reflections from the world (34-59). Ankara: Ozgun Kok Publishing.

Aydin, H., \& Aslan, D. (2016). Determining Attitudes towards Pedagogical Teacher Training: A Scale Development Study. Journal of Education and Learning, 5(3).

Aytan, T. (2011). Effects of active learning techniques on listening skills. (Unpublished doctorate thesis). Selcuk University, Institute of Educational Sciences, Konya.

Aytas, G. (1999). Effective Listening. MEBS Communication, Year: 2 Issue: 5.

Buyukozturk, S.( 2010). A data analysis guide for Social Sciences, Statistics, Applications of Research Design SPSS and interpretation. Ankara: Pegem Academy Publications.

Cihangir-Cankaya, Z. (2012) Re-examining of Listening Skills Scale: A Comparison of listening skills of psychological counseling and guidance students towards several variables. Educational Sciences: Theory \& Practice, 12(4),2370-2376.

Cihangir, Z. (2004). The effect of the effective listening skills training which is given to university students on listening skills. Journal of Turkish Educational Sciences, 2(2), 237-251.

Cuceloglu, D. (2009). From Person to Person, again. Istanbul: Remzi Book House.

Caliskan, N. (2003). The evaluation of classroom teachers' nonverbal communication behavior. [Unpublished doctorate dissertation] Erzurum: Ataturk University.

Ciftci, M. (2001). Factors affecting listening education and listening. Journal of Social Sciences, 165-177.

Ciftci, O. (2007). Active Listening. Journal of National Education. Issue: 176. Ankara MOE Publications.

Cossitt, M. (1978). Curriculum Guide For Elementary Language Arts. Alberta Education.

Dilekman, M., Basci, Z., \& Bektas, F. (2008). Communication Skills of Educational Faculty Students. Journal of Ataturk University Social Sciences Institute, 12(2).

Dogan, Y., \& Ozcakmak, H. (2014). Evaluation of Prospective Turkish Teachers' Summarizing Skills for the Texts Listened. Journal of Mustafa Kemal University Social Sciences Institute, 11(28).

Dokmen, U. (1994). Communication Conflicts in Arts and Daily Life and Empathy. Istanbul: Sistem Publishing. 
Durmusoglu- Saltal1, N., \& Erbay, F. (2013). Examination of speaking, listening and empathy skills of preschool teachers in terms of children liking behaviors. Journal of Kirsehir Education Faculty, 14(1).

Erbay, F., Omeroglu, E. ve Cagdas, A. (2012). Developing of teacher-child communication scale and study of validity and reliability. Journal of Educational Sciences in Theory and Practice, 12(4), 3165-3172.

Emiroglu, S. (2013). The Views of Prospective Turkish Teachers regarding listening problems. Journal of Adiyaman University Social Sciences Institute, 2013 (11).

Epcacan, C. (2013). Listening and listening education as a basic language skill. Journal of Adiyaman University Social Sciences Institute, 2013(11).

Gordon,T. (1996). Effective teaching education. Translator: Emel Aksay. Istanbul: Sistem Publishing.

Gogus, B. (1978). Turkish and literature teaching in our secondary schools. Ankara: Gul Publishing House.

Gokceli , S. (2013). Attitudes of High School Students towards Body Language: Sample of Adana-Kozan Fatih Anatolian High School. Journal of Adiyaman University Social Sciences Institute, 2013(11).

Gunes, F. (2007). SBSM (Sound- based sentence management) and Mental Configuration. Ankara: Nobel Publishing.

Hampleman, R. (1958). Comparison of Listening and Reading Comprehension Ability of 4th and 6th Grade Pupils. Elementary English. XXXI, 49.

Habac1,I., Urker, A., Bulut, S., Atıc1, R., \& Habac1, Z. (2013). Effects of Body Language on Education. Electronic Turkish Studies, 8(9).

Hübler, A. (2001). Das Konzept Körper in den Sprach- und Kommunikationswissenschaften. Tübingen: A. Franke Verlag.

Jalongo, M. R. (1995). Promoting Active Listening in the Clossroom. Childhood Education, 72(1), 13-18.

Johnson, K. O. (1951). The Effect of Classroom Training upon Listening Comprehension. The Journal of Communication, I, 58.

Karasar, N. (2009). Scientific Research Method. Ankara: Nobel Publishing.

Kecik, I., \& ve Uzun, L. (2004). Turkish Verbal and Written Expression. Eskisehir: Anadolu University Open Education Faculty Publications.

Korkut, F. (2005). Communication Skills Education for Adults. Journal of Hacettepe University Educational Faculty, 28(28).

Kurudayioglu, M., \&, Kana, F.. (2013). Listening Skills and Listening Education of Prospective Turkish Teachers and Their Self-Efficacy Perceptions. Mersin University Journal of the Faculty of Education, 9(2), 245-258.

Lafer, S. (2014). Democratic Design for the Humanization of Education. Journal of Ethnic and Cultural Studies, 1(1), 6-12.

Maden, S., \& Durukan, E. (2011). Evaluation of listening types of Prospective Turkish Teachers in terms of diverse variables. Journal of Mehmet Akif ErsoyUniversity Social Sciences Institute, (4), 101-112.

Mert, E. L. (2013). Analysis of Perceptions of Prospective Turkish Teachers related the four basic language skills Through Metaphors. Journal of International Social Research, 6(27).

Oz, M. F. (2001). Applied Turkish Education. Ankara: Ani Publications.

Ozbay, M. (2005). Listening Education as a Language Skill. Bir Dil Becerisi Olarak Dinleme Eğitimi. Ankara: Akcag Publications. Ankara: Akçağ Yayınları.

Ozdemir, E. (1987). Turkish Education Manual for Primary School Teachers. Istanbul: Inkilap Book House.

Ozkan, B. (2011). Views of Prospective Turkish Teachers in respect to the courses of "Understanding Techniques" and "Narrative Techniques". NWSA: Education Sciences, 6(3), 2123-2132.

Rost, M. (1994). Introducing Listening. London: Penguin English Applied Linguistics.

Pala, A. (2008). A Study on the levels of emphathizing of Prospective Teachers. Journal of Pamukkale University Educational Faculty, 1(23), 13-23.

Pehlivan, K. B. (2005). A Study on the Perceptions of Communication Skills of Prospective Teachers. Primary Education Online, 4(2).

Schober, O. (2007). Body Language, Body Language. (Translator: Sueda Ozbent), Istanbul: Arion Publishing House. 
Tabak, G. (2013). The Evaluation of Turkish Teacher Candidates' Listening Styles In Terms Of Some Variables. Journal of Mustafa Kemal University Social Sciences Institute, 10(22), 171-181.

Temur, T. (2010). The effect of pre-test and post-test questions of listening texts on listening comprehension level of university students. Journal of Selcuk University Ahmet Kelesoglu Educational Faculty, 29, 303-319.

Tunceli, H. I. (2013). Examination of the Relationship Between Propective Teachers' Communication Skills and their Attitudes towards the teaching profession. Pegem Education Journal, 3(3), 51-58.

Wolff, F. I., Marsnik, N. C., Tacey, W. S. and Nichols, R. G. (1983). Perceptive Listening. New York: CBS College Publishing.

Umagan, S. (2007). Listening. Turkish Education in Primary Education. (Editors: Ahmet Kirkkilic, Hayati Akyol). Ankara: PegemA Publications.

Yesil, R. (2006). In-class Teaching Proficiency of Social Sciences Teachers. Journal of Ahi Evran University Kirsehir Educational Faculty, 7, 2, 61-78.

Yesil, R. (2009). In-class Teaching Proficiency of Prospective Social Sciences Teachers. Journal of Turkish Educational Sciences, 7(2).

Yoncalik, O., \& Cimen, Z. (2006). Listening Skills Levels of Physical Education and Classroom Teaching Students in Interpersonal Communication. Journal of Gazi University Kirsehir Educational Faculty, 7(1), 135-144.

Yuksel, A. (2004). The effect of empathy education program on the empathic skills of primary school students. Journal of Uludag University Educational Faculty, 17(2), 341-354.

Yurtseven, N. \& Altun, S. (2015). Intercultural Sensitivity in Today's Global Classes: Teacher Candidates' Perceptions. Journal of Ethnic and Cultural Studies, 2(1), 49-54.

Appendix A

\section{LISTENING SKILLS SCALE (LSC)}

You will find expressions which measure other people's listening tendencies below. Please mark with (X) the suitable option for yourself considering the behaviors you have shown in the listening process of communication. Thank you for your attention.
(1) Never
(2) Occasionally
(3) Sometimes
(4) Often
(5) Always

\begin{tabular}{|c|c|c|c|c|c|c|}
\hline 1 & I get bored to listen to the people who don't think like me. & 1 & 2 & 3 & 4 & 5 \\
\hline 2 & I ask questions to understand the person whom I am talking to. & 1 & 2 & 3 & 4 & 5 \\
\hline 3 & I don't like listening to others for a long time. & 1 & 2 & 3 & 4 & 5 \\
\hline 4 & My thoughts shift into another field while listening to someone. & 1 & 2 & 3 & 4 & 5 \\
\hline 5 & I try to make the person I am talking feel that I am willing to understand her/him better. & 1 & 2 & 3 & 4 & 5 \\
\hline 6 & I believe that I don't have to listen to the others for a long time. & 1 & 2 & 3 & 4 & 5 \\
\hline 7 & There are times when I don't listen to someone whom I am talking to. & 1 & 2 & 3 & 4 & 5 \\
\hline 8 & $\begin{array}{l}\text { Understanding the person's feelings and thoughts while listening, I can transfer those feelings } \\
\text { to him/her by my verbal or non-verbal behaviors. }\end{array}$ & 1 & 2 & 3 & 4 & 5 \\
\hline 9 & $\begin{array}{l}\text { When a conflict occurs, I try to listen patiently to the person whom I am talking to understand } \\
\text { her/his feelings and thoughts. }\end{array}$ & 1 & 2 & 3 & 4 & 5 \\
\hline 10 & There are times when I pretend to listen to someone even though I don't listen to him/her. & 1 & 2 & 3 & 4 & 5 \\
\hline 11 & While listening to someone, I try to put myself into her/his shoes. & 1 & 2 & 3 & 4 & 5 \\
\hline 12 & I have a difficulty to make an eye contact the person whom I am listening to. & 1 & 2 & 3 & 4 & 5 \\
\hline 13 & While listening to someone, I would make sure that my body faces towards him/her. & 1 & 2 & 3 & 4 & 5 \\
\hline 14 & While listening to someone, I care about her/his verbal and non-verbal messages. & 1 & 2 & 3 & 4 & 5 \\
\hline 15 & While listening to someone, I try to understand her/his feelings. & 1 & 2 & 3 & 4 & 5 \\
\hline
\end{tabular}

